Session 1608

\title{
A Systematic Approach to Satisfying EC2000
}

\author{
Debra L. Hawker-Schreiner, Charles E. Glatz, \\ Richard C. Seagrave \& R. Dennis Vigil \\ Department of Chemical Engineering, Iowa State University
}

\begin{abstract}
When considering the requirements of EC2000 ${ }^{1}$, it rapidly becomes apparent that a large amount of data is going to be produced, and that it must be used. Additionally, the data required must be obtained from different constituencies and there may not be significant additional resources to maintain long term monitoring. These facts were considered when beginning the process to satisfy EC2000 in the Chemical Engineering Department at Iowa State University (ISU). The solution followed four basic rules. 1) Ensure that all of the assessment techniques used have a common basis. Thus, the data obtained from various techniques can easily be compared and common trends noted. 2) Do not reinvent the wheel, if a mechanism or an assessment technique is already in place, use it. Modify it, if necessary, instead of starting from scratch. One of the major benefits of this approach is that those involved are already familiar with the mechanism or technique. 3) Use the data from each assessment technique to the fullest. This has a twofold benefit: there is less data manipulation required and each constituency is not plagued by repetitive requests for data. 4) Do not obtain unnecessary data. The trick here is that it first must be determined what is necessary. By following the four rules, the program was able to develop mechanisms and assessment techniques that are useful, satisfy EC2000 and can be maintained. Specifically, data is collected using the following assessment techniques: student course evaluations, instructor course feedback forms, course portfolios, senior survey, junior survey, alumni survey and an annual placement analysis. These data are used to improve the program via the following mechanisms: industrial advisory committee annual meeting, annual program review, annual department retreat, department committees, direct distribution to faculty and faculty meetings. Any program changes are noted in the process improvement log.
\end{abstract}

\section{Introduction}

Preparing for accreditation under EC2000 is different from preparing for past accreditation visits. Previously the process involved ascertaining that the program satisfied the strictly outlined requirements, correcting any problems that had been noted previously, and then documenting how the program satisfies the requirements in the self-study and collecting materials for the accreditation visit. Now, instead of a set of strictly outlined requirements, there are some strict requirements but also a set of general criteria that are to be interpreted by the program, depending on the unique needs of the program. Engineers tend to look for "the solution" or "the approach" to the problem, in this case the problem being how to satisfy EC2000. Part of the

Proceedings of the 2001 American Society for Engineering Education Annual Conference \& Exposition Copyright (C) 2001, American Society for Engineering Education 
beauty of the new criteria is that each program has some leeway with regard to how to satisfy the criteria, this also, however, presents the complication in that satisfying EC2000 no longer has a solution or one approach. Here the approach taken by the Chemical Engineering program at ISU to satisfy "Criterion 3. Program Outcomes and Assessment" and "Criterion 8. Professional Component" is discussed. Though the information is presented here in an organized fashion it is important to note that the process by which the preparation occurred was not always orderly or completed in a logical fashion. The path by which a program arrives at its solution is part of learning what works for the program.

\section{Basic groundwork}

The majority of programs preparing for accreditation under EC2000 have successfully been accredited previously under the former criteria. Thus, the programs have, in general, a good strong basis and need not rebuild their programs from scratch. ${ }^{2}$ That being said, some programs have the time, energy and desire to take this opportunity to scrutinize their programs from the ground up and rebuild. The faculty of the Chemical Engineering program at ISU found that they had a strong basis on which to build for EC2000. Therefore, the EC2000 criteria were used to study and modify the program but the program was not rebuilt from scratch.

It was also necessary to identify the constituents who would be involved in the assessment process. The constituents include: the program faculty, the program staff, the program student body, the program's alumni, the employers of the alumni, the college, the university, the state, the parents of students in the program, and many others. With regard to the techniques described herein, the first five groups are actively engaged in the process.

Once the constituent groups were identified, it was determined what EC2000 Criteria 3. and Criteria 8. meant to the program. For the most part, the program offers courses that correspond to the professional component and the syllabi from these courses were used to describe these criteria. With respect to the Criteria 3., the outcomes were expanded or defined, in a manner similar to that used by the Chemical Engineering Program at Michigan State University. ${ }^{3}$ These steps are critical as they provide the common basis for all of the assessment techniques.

Another key to the process is one that has been noted before: it is necessary to have a key faculty member or a core group of faculty members involved consistently in the process in order to use time effectively and maintain momentum. ${ }^{4}$ This is not to say that all of the faculty are not involved in the process, rather, they are tapped on to provided information and services to the process along the way, allowing them to develop familiarity with the tools as they are developed. Consistency in faculty involvement also helps to maintain a consistent core to the process.

\section{Assessment techniques used}

There are many assessment techniques that can be used and the program chose those described here based on past experience and the desire to produce useful information in a timely fashion while minimizing the resources required to maintain the instruments, thereby helping to insure

\footnotetext{
Proceedings of the 2001 American Society for Engineering Education Annual Conference \& Exposition
} Copyright (O) 2001, American Society for Engineering Education 
Table I. Facts on Assessment Techniques

\begin{tabular}{|c|c|c|c|c|c|}
\hline Assessment Technique & 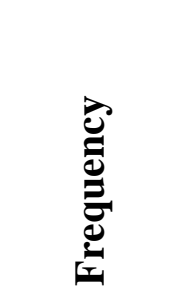 & 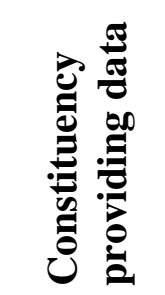 & 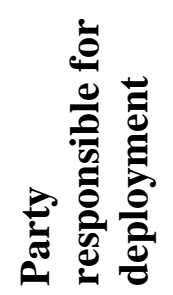 & 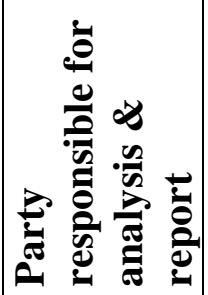 & 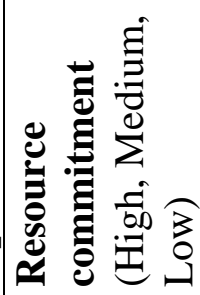 \\
\hline Student course evaluations & $\begin{array}{c}\text { Each } \\
\text { Semester }\end{array}$ & Students & $\begin{array}{l}\text { Staff \& } \\
\text { Faculty }\end{array}$ & $\begin{array}{l}\text { Testing } \\
\text { Services }\end{array}$ & Low \\
\hline $\begin{array}{l}\text { Instructor course feedback } \\
\text { forms }\end{array}$ & $\begin{array}{c}\text { Each } \\
\text { Semester }\end{array}$ & Faculty & $\begin{array}{l}\text { Staff \& } \\
\text { Faculty }\end{array}$ & $\begin{array}{l}\text { None } \\
\text { required }\end{array}$ & Low \\
\hline Senior survey & Annual & Students & Faculty & $\begin{array}{c}\text { DEO } \\
\text { Designee }\end{array}$ & High \\
\hline Junior survey & Annual & Students & Faculty & $\begin{array}{c}\text { DEO } \\
\text { Designee }\end{array}$ & Medium \\
\hline Alumni survey & $\begin{array}{l}\text { Even } \\
\text { years }\end{array}$ & Alumni & Faculty & $\begin{array}{c}\text { DEO } \\
\text { Designee }\end{array}$ & High \\
\hline Annual placement analysis & Annual & Students & ECS & $\begin{array}{c}\text { DEO } \\
\text { Designee }\end{array}$ & Medium \\
\hline
\end{tabular}

- Department Executive officer

long term stability. Basic facts for each of the assessment techniques are shown in Table I. Each of the techniques is designed to provide useful information while economizing on the resources required obtaining the information.

Student Course Evaluations have been in use in the program for a number of years. This technique allows for rapid feedback to the faculty while requiring a minimum of time for administration, maintenance, and data manipulation. The results of the evaluations are available prior to the beginning of the subsequent term; thus the information gleaned can be applied rapidly. The content and format of the course evaluations was modified to reflect EC2000. Specifically, the first seven questions come directly from the previously used college prescribed form and provide information with regard to instructor teaching effectiveness, instructor availability, appropriateness of course materials and classroom environment. The remaining questions are based on the primary outcomes to which the course is expected to contribute, as defined in the course description. The evaluations are completed on multiple choice bubble sheets each semester in each of the undergraduate courses. Room for comments is also provided and often used for additional questions posed by the instructor. The Testing Services group at ISU completes the analysis of the data and generates the reports that are sent back to the department. A report is generated for each course as well as overall reports for multiple sections of the same course and one for all sections and courses for the first seven questions, which are common on all forms. The reports include average result, variance and tallies of each response. An example Student Course Evaluation is shown in Appendix I.

Proceedings of the 2001 American Society for Engineering Education Annual Conference \& Exposition Copyright (C) 2001, American Society for Engineering Education 
Instructor Course Feedback Forms are a technique new to the program that allow the instructor to provide information on assessment techniques, course materials and course outcomes. The questions regarding the course outcomes again come from the course description, allowing for both the instructor and the students to evaluate the same material. This aids the curriculum committee, and other interested parties, in determining what is or is not working as desired in a given course. The forms require no post processing and are completed each semester for each of the undergraduate courses. An example Course Feedback Form is shown in Appendix II.

The Senior Survey is the workhorse of the surveys used in the program. Senior surveys have been in place in the program for a number of years and have been modified to provide data relevant to EC2000. Students complete the survey in the capstone design course and therefore tend to be graduating in the current semester or have only a term left prior to graduation. As this is the case, a large amount of information covering a wide range of topics is gleaned from the students. They are asked to provide information regarding: their confidence in their abilities with regard to Criterion 3. and Criterion 8., the opportunities they perceived as being available to them in order to improve or attain the abilities, the advisor/advisee relationship, positive and negative experiences within the department and their undergraduate experience, facilities available within the department, their professional experiences, and their extracurricular activities. When the students are asked about the opportunities available to them it is clarified that they should include all opportunities and that the coursework itself is only part of their overall learning experience. The information is garnered both through multiple choice and openended questions. The data obtained can be used to support that obtained through any of the other techniques as basic content is the same. A detailed analysis is performed on the data. This includes: calculating average responses, reading and classifying comments to look for common threads, comparing current results to those obtained previously, preparing individual reports for advisors with comments from their advisees, and preparing reports with and without specific courses and instructors being named.

The focus of the Junior Survey is the advising system within the department. This survey has been in place for several years with slight modifications. Students are asked which resources they consider to be the most helpful for a variety of situations, such as receiving career assistance and obtaining various forms. A report is generated consisting of tallies of the responses, computation of averages and variances, and evaluating comments for general trends. This information is discussed with the students to help determine what changes should be made to the advising system. One of the major outcomes of this process was the development of a departmental undergraduate booklet which contains answers to most common questions and is available online as well as in hardcopy.

The Alumni Survey is designed to obtain feedback from as great a percentage of graduates as possible that have graduated from the program within the last 2-5 years. As a result, it is one of the shorter surveys but has features that make it effective. This is a relatively new survey for the program and has been deployed twice. The alumni are asked to provide information regarding: when they graduated, the type of work they currently do, the type of work they have been involved in since graduation, the types of additional education or training they have pursued,

Proceedings of the 2001 American Society for Engineering Education Annual Conference \& Exposition Copyright (C) 2001, American Society for Engineering Education 
how prepared they felt to enter their career at graduation and how important various activities were to their professional development. In addition, they are asked to rank how important the components of Criterion 3. and Criterion 8. are to their career. They are also asked to provide comments on their experiences, suggestions for improvements to the program, and any weaknesses that they perceive looking back on the program. All of the preceding information is provided anonymously. They are then asked to provide on a separate sheet their contact information if they are willing to discuss their experiences further, if they supervise new graduates and would like to provide information from that perspective or if they are interested in participating in various activities with the department. Thus, any concerns that become apparent from the basic survey can be researched further if necessary. In addition, the program gains access to alumni that are willing to aid the department in a variety of ways. A detailed report is prepared from the information garnered, similar to that prepared for the Senior Survey.

The Annual Placement Analysis has been completed for three years and uses information provided by the ISU Engineering Career Services to determine when graduates are placed and the types of fields which the graduates tend to enter. Trends of student placement are tracked and compared with those provided by the American Institute of Chemical Engineers. This allows the department to note and respond to trends that may not be immediately obvious.

The Course Portfolios, which have been in use for two years, provide a means by which information can be transmitted between instructors, to the curriculum committee, or to other interested parties. Specifically, they form a repository of course information including, but not limited to, instructor course feedback forms, syllabi, exams, assignments, course notes, etc. Instructors submit materials each term for the course portfolios.

IV. Use of assessment data and the process improvement process

The data garnered using the techniques described in the previous section are used to provide information to groups and individuals. The information is then used to recommend changes to the program, track trends within the program, program management, or course or individual development. The distribution of the data is summarized in Table II. The key to the successful use of the data is customizing the data for each function by preparing specific reports where necessary. Thus, every assessment technique in use produces information that is used by several different entities within the program. It is important to note that in the creation of the reports, confidential information is only available to those that need it, typically the individual involved and perhaps the DEO. At all other times, confidential information in the form of names, course numbers or other identifying marks, is replaced with generic information, such as "Dr. X".

The garnered data are used in the process as shown in Table III and Figure 1. Table III details facts regarding the mechanisms used. Note that at a minimum the mechanisms present in the process occur on an annual basis. All constituencies are represented in the processes, and in many cases the constituencies work together to provide suggestions for the program. In addition, as with the assessment techniques, the resource commitment is kept low while attaining as much information, insight and interaction as possible.

Proceedings of the 2001 American Society for Engineering Education Annual Conference \& Exposition Copyright (C) 2001, American Society for Engineering Education 
Table II. Uses of assessment data

\begin{tabular}{|c|c|c|c|c|c|c|c|c|c|c|}
\hline \multirow{2}{*}{\multicolumn{2}{|c|}{$\begin{array}{c}\text { Assessment Technique } \\
\& \\
\text { Data Communicated }\end{array}$}} & \multicolumn{9}{|c|}{ Destination of Data } \\
\hline & & \multirow[t]{2}{*}{ 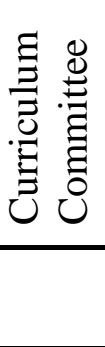 } & \multirow{2}{*}{ 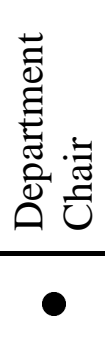 } & 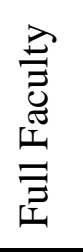 & \multirow{2}{*}{ 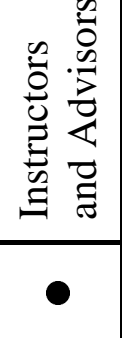 } & 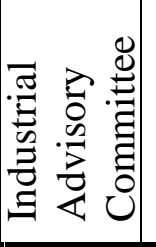 & 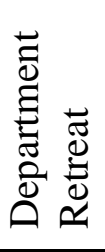 & \multirow[t]{2}{*}{ 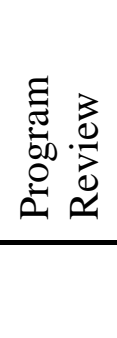 } & \multirow[t]{2}{*}{ 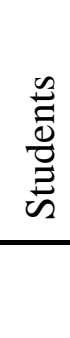 } & \multirow[t]{2}{*}{ 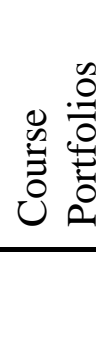 } \\
\hline \multirow{2}{*}{$\begin{array}{l}\text { Student } \\
\text { course } \\
\text { evaluations }\end{array}$} & $\begin{array}{l}\text { Complete } \\
\text { report }\end{array}$ & & & & & & & & & \\
\hline & $\begin{array}{l}\text { Outcome } \\
\text { specific } \\
\text { information }\end{array}$ & • & & & & $\odot$ & $\odot$ & $\odot$ & & \\
\hline $\begin{array}{l}\text { Instructor } \\
\text { course } \\
\text { feedback } \\
\text { forms }\end{array}$ & $\begin{array}{l}\text { Complete } \\
\text { report }\end{array}$ & - & & & & $\odot$ & $\odot$ & $\odot$ & & • \\
\hline \multirow{4}{*}{$\begin{array}{l}\text { Senior } \\
\text { survey }\end{array}$} & $\begin{array}{l}\text { Complete } \\
\text { report w/ } \\
\text { complete } \\
\text { comments }\end{array}$ & & $\bullet$ & & & $\diamond$ & $\odot$ & $\odot$ & & \\
\hline & $\begin{array}{l}\text { Complete } \\
\text { report w/ } \\
\text { cleaned } \\
\text { comments }\end{array}$ & - & & - & & - & & & & \\
\hline & $\begin{array}{l}\text { Complete } \\
\text { report w/o } \\
\text { comments }\end{array}$ & & & & & & & & - & \\
\hline & $\begin{array}{l}\text { Individual } \\
\text { Advisor } \\
\text { Reports } \\
\end{array}$ & & & & - & & & & & \\
\hline $\begin{array}{l}\text { Junior } \\
\text { survey }\end{array}$ & $\begin{array}{l}\text { Complete } \\
\text { report * }\end{array}$ & & - & & & & & & • & \\
\hline $\begin{array}{l}\text { Alumni } \\
\text { survey }\end{array}$ & $\begin{array}{l}\text { Complete } \\
\text { report }\end{array}$ & - & $\bullet$ & - & & • & $\odot$ & $\odot$ & & \\
\hline $\begin{array}{l}\text { Annual } \\
\text { placement } \\
\text { analysis }\end{array}$ & $\begin{array}{l}\text { Complete } \\
\text { report }\end{array}$ & & - & - & & & & & & \\
\hline
\end{tabular}

- Report typically will be used by the group/individual receiving it

$\odot \quad$ May or may not be part of the information provided to the group depending on the decision of the discussion coordinator

* This report is also provided to the advising coordinator

- The coordinating member of the industrial advisory committee only

Proceedings of the 2001 American Society for Engineering Education Annual Conference \& Exposition

Copyright $\odot$ 2001, American Society for Engineering Education 
Table III. Facts on Process Improvement Mechanisms

\begin{tabular}{|c|c|c|c|c|c|}
\hline Mechanism & 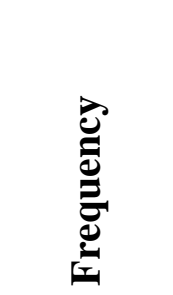 & 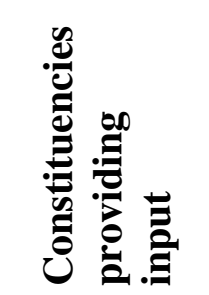 & 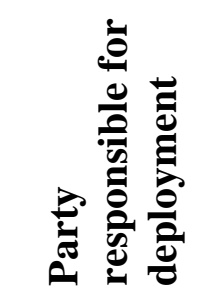 & 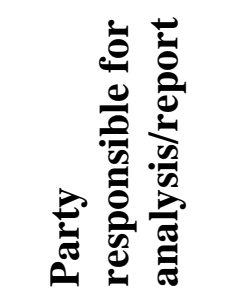 & 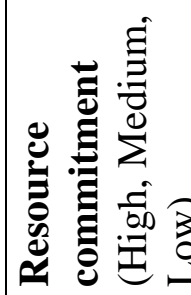 \\
\hline $\begin{array}{l}\text { Industrial Advisory } \\
\text { Committee [IAC] }\end{array}$ & Annual & $\begin{array}{c}\text { Students } \\
\text { Alumni } \\
\text { Employers } \\
\text { Faculty }\end{array}$ & $\begin{array}{l}\text { DEO and } \\
\text { designees }\end{array}$ & IAC & Medium \\
\hline Program Review & Annual & $\begin{array}{l}\text { Students } \\
\text { Alumni } \\
\text { Employers } \\
\text { Faculty }\end{array}$ & $\begin{array}{l}\text { Assessment } \\
\text { coordinator } \\
\text { /Chair of } \\
\text { curriculum } \\
\text { committee }\end{array}$ & $\begin{array}{l}\text { Assessment } \\
\text { coordinator } \\
\text { /Chair of } \\
\text { curriculum } \\
\text { committee }\end{array}$ & Medium \\
\hline Departmental Retreat & Annual & $\begin{array}{c}\text { Students } \\
\text { Alumni } \\
\text { Employers } \\
\text { Faculty }\end{array}$ & $\begin{array}{l}\text { DEO and } \\
\text { designees }\end{array}$ & $\begin{array}{l}\text { DEO and } \\
\text { designees }\end{array}$ & Medium \\
\hline Departmental Committees & $\begin{array}{c}\text { As } \\
\text { needed }\end{array}$ & Varies & $\begin{array}{c}\text { Chair of } \\
\text { Committee }\end{array}$ & $\begin{array}{c}\text { Chair of } \\
\text { Committee }\end{array}$ & Varies \\
\hline $\begin{array}{l}\text { Direct Distribution to } \\
\text { Faculty }\end{array}$ & $\begin{array}{l}\text { As data } \\
\text { is } \\
\text { produced }\end{array}$ & Varies & $\begin{array}{c}\text { DEO } \\
\text { designee }\end{array}$ & Varies & Low \\
\hline Faculty Meetings & $\begin{array}{c}\text { As } \\
\text { needed }\end{array}$ & Varies & N/A & Varies & Low \\
\hline
\end{tabular}

The Industrial Advisory Committee meeting is a one-and-a-half-day meeting that occurs in the fall. The committee consists of alumni, employers, and faculty from other institutions. As part of the meeting, the committee meets with seniors who have completed the Senior Survey and discusses with them any strengths or weaknesses in the program. This is done in the absence of faculty or staff and helps to clarify the findings of the Senior Survey. The committee is provided with the report on the Senior Survey prior to their arrival on campus. In addition to discussing the Senior Survey, other issues are discussed at the discretion of the DEO, the committee and the faculty. The committee's findings result in recommendations that are passed on to the faculty.

The Program Review is a half-day meeting that occurs in the spring. This meeting includes alumni and employers who are present for a coinciding career fair as well as current students and faculty. The coordinating faculty member, in conjunction with the DEO, determines the focus of the meeting, and relevant information is provided to the participants prior to the meeting. The outcome of this meeting is recommendations that are passed on to the faculty.

Proceedings of the 2001 American Society for Engineering Education Annual Conference \& Exposition Copyright (C) 2001, American Society for Engineering Education 


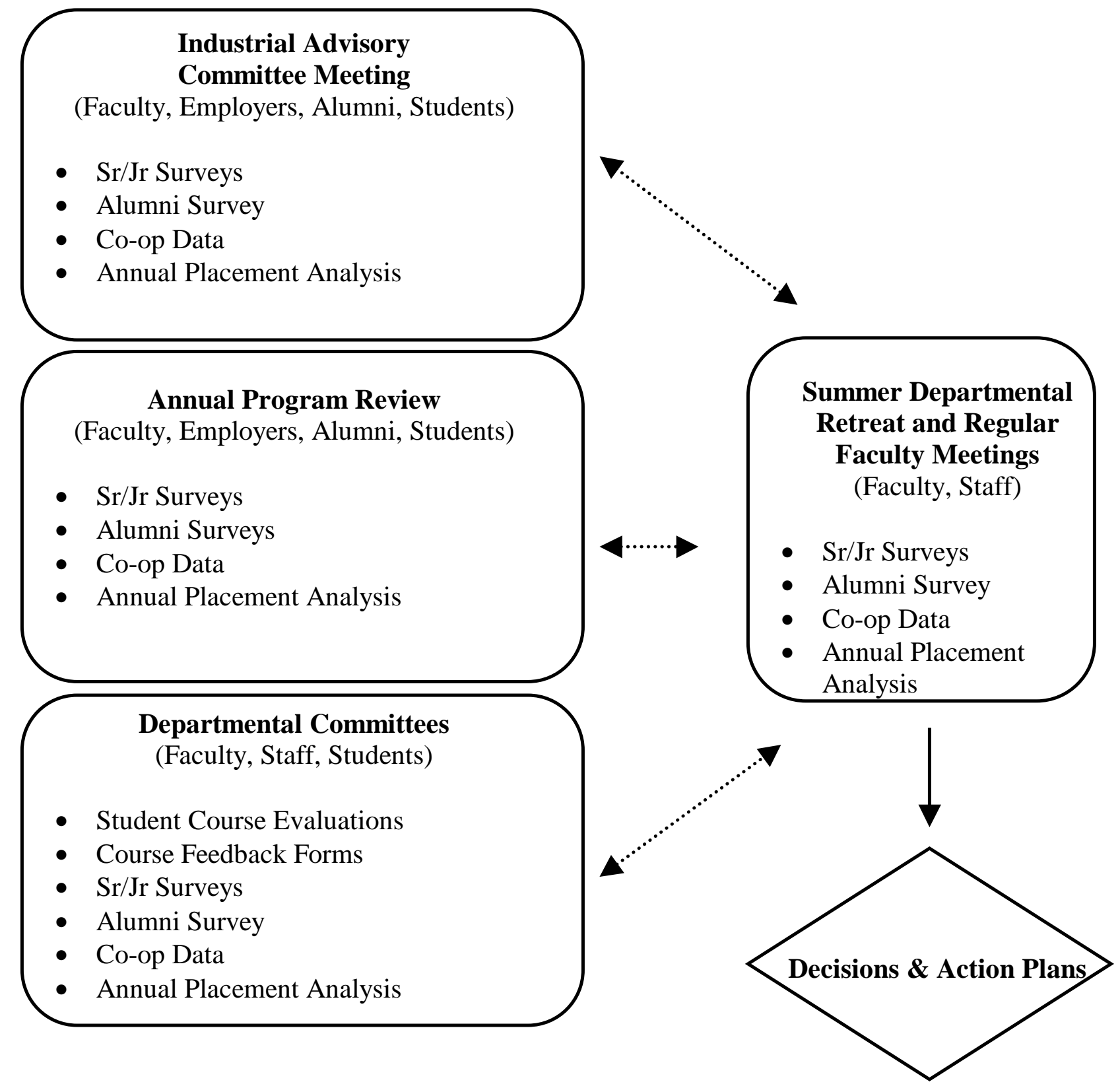

Figure 1 - Program Improvement Process

Proceedings of the 2001 American Society for Engineering Education Annual Conference \& Exposition

Copyright (C) 2001, American Society for Engineering Education 
The various departmental committees, in particular the curriculum committee, have access to a wide variety of assessment data which may be used to direct and support their recommendations and decisions. In some cases the committee will implement changes as the point in question falls under their jurisdiction, while at others the committee will bring the issue to the attention of the full faculty.

One part of the process not illustrated is the Annual Review of Faculty. The DEO and individual faculty member have access to confidential as well as general information. With these data the individual faculty members develop action plans in conjunction with the DEO.

Each of the mechanisms in the Program Improvement Process has a variety of assessment inputs available, and the coordinators determine the extent to which each is used. Thus there is immediately a data flow established between the faculty and those involved in the mechanism. The recommendations that result from the mechanism are acted on during regular faculty meetings or during the Departmental Retreat. The Departmental Retreat is an all-day meeting that allows for the faculty to focus on a few key issues in a short period of time.

The Program Improvement Process allows for rapid action when warranted, but also allows for the observation of information gathered over time so that changes can also occur as a result of slow moving trends. Thus, the program expects to continually improve using this process, but not change at such a rate that the changes are not adequately controlled or such that the effects of the changes cannot be monitored effectively.

In order to monitor the changes in the program, a Process Improvement Log was developed. This log notes a summary of the change, when the change occurred, the input from constituencies and assessment data which were considered, and the pertinent text of the minutes from the faculty meeting or retreat which describe the event. The log fulfills two vital functions. First, it provides an easily accessible record of the changes that have been made to show that the process does in fact work. Second, it provides a record that may be used to assess the utility of the assessment instruments.

\section{Future plans}

Part of the beauty of EC2000 is that it allows a program and its processes to change and develop as necessary. The program is looking forward to further developing its processes and assessment techniques following a successful accreditation visit in the fall of 2000. Specifically, the program will be undergoing several subtle changes in the curriculum, directly as a result of the data obtained from the assessment techniques. In addition, the assessment techniques themselves will be undergoing modification. The surveys will soon be available in an internet format and the assessments related to the courses will have questions relevant to collaborative education techniques incorporated. There will also be opportunity to assess the utility of new data that is becoming available as Engineering Career Services is incorporating a new system to assess cooperative education. This system should provide significant data to the students and it is hoped that the program will also be able to make direct use of some of the data. The college has also embarked on a more stringent technique for tracking students and it is hoped that this will

Proceedings of the 2001 American Society for Engineering Education Annual Conference \& Exposition Copyright (C) 2001, American Society for Engineering Education 
also provide the program with useful information regarding the mobility of students in and out of the program.

Overall, the program has developed assessment tools with which it is comfortable and which provide the data that is needed while not providing extraneous data. In addition, the mechanisms that use the data produced, and which constitute the Program Improvement Process, are operating effectively without taxing the program resources and are proving to be sustainable.

Bibliography

1. Engineering Accreditation Commission Criteria for Accrediting Engineering Programs, URL: www.abet.org .

2. Seagrave, R.C. ABET Engineering Criteria 2000, Case Study I: Coastal State University, URL: www.abet.org/eac/case1.htm.

3. Personal communication.

4. URL: http://www.abet.org/eac/ec2000_Lessons_Learned.htm

Appendix I. Example of a student course evaluation

\section{Course \& Instructor Assessment}

\section{Chemical Engineering 210}

TO THE STUDENT: Student assessment of the course and instructor are important components of our continuous improvement strategy. It is, therefore, a vital part of your responsibility as a student to give reasoned opinions to the items below. These forms with summary results will not be returned to the instructor until after the final grades for the course have been submitted.

Please mark your answers with a soft black PENCIL. Ink marks will not be read by the scanner.

1. The text materials for this course were:
1) Too elementary 2) Too difficult 3) Satisfactory

2. The pace of this course was:

1) Too slow 2) Too fast 3) Satisfactory

3. The objectives of this course were:

1) Not stated 2) Not attained 3) Attained

For questions 4 to 7 , select one of the following responses:
1) Poor
2) Marginally satisfactory
3) Satisfactory
4) Good 5) Excellent

4. The extent to which the instructor created a positive learning environment in which you felt comfortable was:

5. The fairness shown by the instructor was:

6. The instructor's availability outside the classroom was:

7. The overall teaching effectiveness of the instructor was:

Proceedings of the 2001 American Society for Engineering Education Annual Conference \& Exposition

Copyright (C) 2001, American Society for Engineering Education 
For questions 8 to 16 , select one of the following responses:
1) Strongly disagree
2) Disagree
3) Somewhat agree
4) Agree
5) Strongly agree

8. You understand and are able to develop and use material and energy balance equations:

9. You can create process diagrams for simple and moderately complex chemical systems:

10. You can solve material and energy balance problems using various computational tools:

11. This course provided you with an opportunity to develop an ability to identify, formulate and solve engineering problems:

12. This course provided you with an opportunity to develop skills in engineering design:

13. This course provided you an opportunity to consider safety and environmental issues:

14. This course provided you with an opportunity to work effectively as a member of a team:

15. This course provided you with an opportunity to demonstrate knowledge through presentation of technical information:

16. This course provided you with an opportunity to understand the nature of chemical engineering, so that you are able to determine if the field is exciting to you:

Please use the back of the form to add additional comments.

Appendix II. Example of a course feedback form, excluding response and comment space.

\section{Course Feedback Form}

Please return this form and materials for course portfolios [syllabi, exams, assignments, handouts, comments on student performance on exams or assignments, and any additional material] to the Student Services Office.

Course: ChE 210 Instructor:

Term:

Was this your first time teaching this course? yes no

Please indicate how the following assessment techniques were used in the course and your judgment of their usefulness.

\begin{tabular}{|c|c|c|c|c|c|c|}
\hline Assessment Technique & Not Used & $\begin{array}{l}\text { Used, } \\
\text { provided } \\
\text { useful data }\end{array}$ & $\begin{array}{l}\text { Used, not } \\
\text { recom- } \\
\text { mended }\end{array}$ & $\begin{array}{l}\text { Data used for } \\
\text { class } \\
\text { management }\end{array}$ & \begin{tabular}{|l} 
Data \\
incorporated \\
in student \\
grades \\
\end{tabular} & $\begin{array}{l}\text { Data used } \\
\text { for student } \\
\text { feedback }\end{array}$ \\
\hline \multicolumn{7}{|l|}{ Graded Homework } \\
\hline \multicolumn{7}{|l|}{ Exams } \\
\hline \multicolumn{7}{|l|}{ Instructor Observation } \\
\hline \multicolumn{7}{|l|}{ Projects } \\
\hline \multicolumn{7}{|l|}{ Written Reports } \\
\hline Oral Reports & & & & & & \\
\hline
\end{tabular}

Proceedings of the 2001 American Society for Engineering Education Annual Conference \& Exposition Copyright (C) 2001, American Society for Engineering Education 


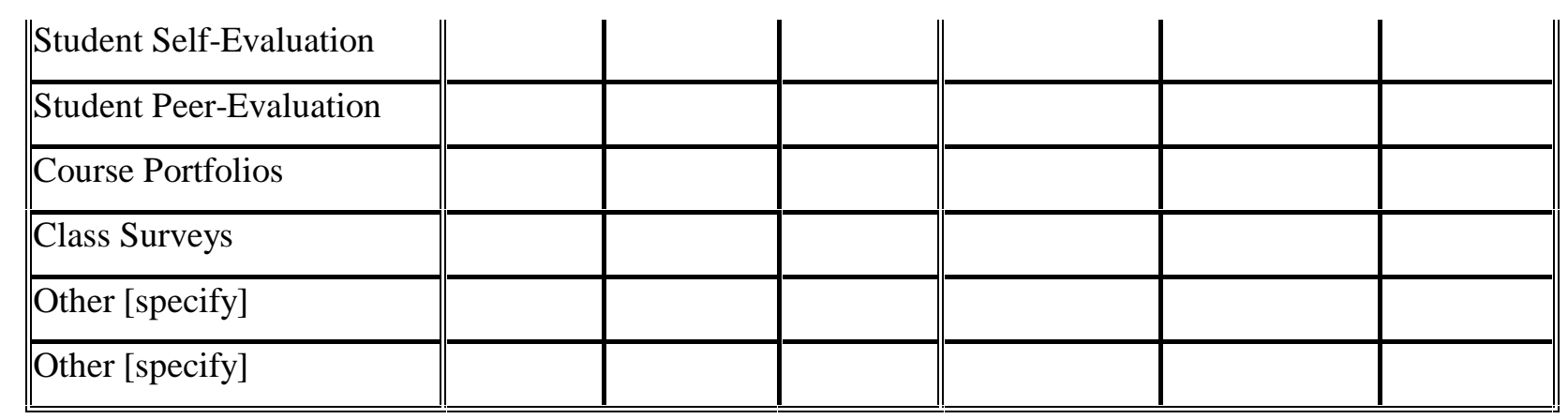

\section{Course Learning Objectives}

On the following table, please indicate your perception of the level of opportunity provided to the students for each of the Course Learning Objectives.

\begin{tabular}{|lccccccc|}
\hline Learning Objective & $\begin{array}{l}\text { Little/No } \\
\text { Opportunity }\end{array}$ & $\begin{array}{l}\text { Moderate } \\
\text { Opportunity }\end{array}$ & $\begin{array}{l}\text { Considerable } \\
\text { Opportunity }\end{array}$ & N/A \\
\hline $\begin{array}{l}\text { Knowledge of Overall and Specie } \\
\text { Material Balances }\end{array}$ & 1 & 2 & 3 & 4 & 5 & N/A \\
\hline $\begin{array}{l}\text { Knowledge of Single Phase and } \\
\text { Multiphase Energy Balances }\end{array}$ & 1 & 2 & 3 & 4 & 5 & N/A \\
\hline $\begin{array}{l}\text { Knowledge of Balances for Single } \\
\text { and Multiple Process Units }\end{array}$ & 1 & 2 & 3 & 4 & 5 & N/A \\
\hline $\begin{array}{l}\text { Knowledge of Balances for Single } \\
\text { and Multiple Reactions }\end{array}$ & 1 & 2 & 3 & 4 & 5 & N/A \\
\hline $\begin{array}{l}\text { Knowledge to Obtain or Determine } \\
\text { Thermodynamic Properties }\end{array}$ & 1 & 2 & 3 & 4 & 5 & N/A \\
\hline $\begin{array}{l}\text { Knowledge of the Utility \& Use of } \\
\text { Process Diagrams }\end{array}$ & 1 & 2 & 3 & 4 & 5 & N/A \\
\hline $\begin{array}{l}\text { Knowledge of Means of Solving } \\
\text { Multiple Balance Equations }\end{array}$ & 1 & 2 & 3 & 4 & 5 & N/A \\
\hline $\begin{array}{l}\text { Knowledge of Safety and } \\
\text { Environmental Issues }\end{array}$ & 1 & 2 & 3 & 4 & 5 & N/A \\
\hline
\end{tabular}

Are there any additions or deletions to the Course Learning Objectives that you feel are appropriate for this course? Please give your reasoning.

Are there any techniques which you found to be particularly useful or useless in attaining the Course Learning Objectives?

Please indicate which text(s) were used and comment on their appropriateness.

Proceedings of the 2001 American Society for Engineering Education Annual Conference \& Exposition Copyright (C) 2001, American Society for Engineering Education 


\section{Departmental Program Objectives}

On the following table, please indicate your perception of the level of opportunity provided to the students for each of the Departmental Program Objectives in this course.

\begin{tabular}{|lcccccc|}
\hline Program Objective & $\begin{array}{l}\text { Little/No } \\
\text { Opportunity }\end{array}$ & $\begin{array}{l}\text { Moderate } \\
\text { Opportunity }\end{array}$ & $\begin{array}{l}\text { Considerable } \\
\text { Opportunity }\end{array}$ & N/A \\
\hline $\begin{array}{l}\text { a) An ability to apply knowledge of } \\
\text { mathematics, science, and } \\
\text { engineering. }\end{array}$ & 1 & 2 & 3 & 4 & 5 & N/A \\
\hline $\begin{array}{l}\text { c) An ability to design a chemical } \\
\text { engineering system, component, or } \\
\text { process to meet desired needs. }\end{array}$ & 1 & 2 & 3 & 4 & 5 & N/A \\
\hline $\begin{array}{l}\text { d) An ability to function on an } \\
\text { interdisciplinary teams. }\end{array}$ & 1 & 2 & 3 & 4 & 5 & N/A \\
\hline $\begin{array}{l}\text { e) An ability to identify, formulate, } \\
\text { and solve chemical engineering } \\
\text { problems. }\end{array}$ & 1 & 2 & 3 & 4 & 5 & N/A \\
\hline $\begin{array}{l}\text { g) An ability to communicate } \\
\text { effectively. }\end{array}$ & 1 & 2 & 3 & 4 & 5 & N/A \\
\hline $\begin{array}{l}\text { k) An ability to use the techniques, } \\
\text { skills, and modern engineering tools } \\
\text { necessary for engineering practice. }\end{array}$ & 1 & 2 & 3 & 4 & 5 & N/A \\
\hline
\end{tabular}

Are there any additions or deletions to the Departmental Program Objectives that you feel are appropriate for this course? Please give your reasoning.

\section{DEBRA HAWKER-SCHREINER}

Debra L. Hawker-Schreiner is a temporary instructor in the Chemical Engineering Department at Iowa State University. She is completing her doctoral degree from the University of Colorado at Boulder and is a graduate of the University of Colorado at Boulder and the University of New Mexico.

CHARLES GLATZ

Charles E. Glatz is a Professor and Chair of the Chemical Engineering Department at Iowa State University. He is a graduate of the University of Wisconsin and the University of Notre Dame.

\section{RICHARD SEAGRAVE}

Richard C. Seagrave is a Distinguished Professor of Chemical Engineering and Interim President at Iowa State University. He is a past chair of the Engineering Accreditation Commission of ABET and is also an AIChE fellow.

\section{DENNIS VIGIL}

R. Dennis Vigil is an Assistant Professor of Chemical Engineering at Iowa State University where he currently chairs the curriculum committee. He is a graduate of the University of Michigan and the University of New Mexico. 